\title{
The Role of Crowdfunding in Moving towards a Sustainable Society
}

Testa, Stefania; Nielsen, Kristian Roed; Bogers, Marcel; Cincotti, Silvano

\author{
Document Version \\ Accepted author manuscript \\ Published in: \\ Technological Forecasting and Social Change \\ DOI: \\ 10.1016/j.techfore.2018.12.011 \\ Publication date: \\ 2019 \\ License \\ CC BY-NC-ND
}

Citation for published version (APA):

Testa, S., Nielsen, K. R., Bogers, M., \& Cincotti, S. (2019). The Role of Crowdfunding in Moving towards a Sustainable Society. Technological Forecasting and Social Change, 141, 66-73.

https://doi.org/10.1016/j.techfore.2018.12.011

Link to publication in CBS Research Portal

\section{General rights}

Copyright and moral rights for the publications made accessible in the public portal are retained by the authors and/or other copyright owners and it is a condition of accessing publications that users recognise and abide by the legal requirements associated with these rights.

\section{Take down policy}

If you believe that this document breaches copyright please contact us (research.lib@cbs.dk) providing details, and we will remove access to the work immediately and investigate your claim.

Download date: 26. Apr. 2023

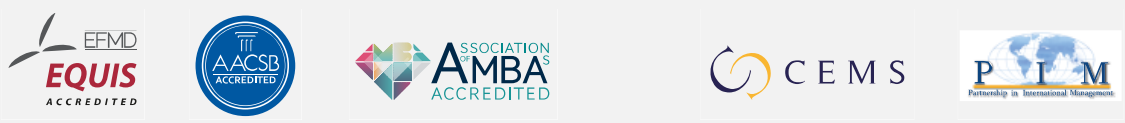




\section{The Role of Crowdfunding in Moving towards a Sustainable Society \\ Stefania Testa, Kristian Roed Nielsen, Marcel Bogers, Silvano Cincotti}

Journal article (Accepted manuscript*)

Please cite this article as:

Testa, S., Nielsen, K. R., Bogers, M., \& Cincotti, S. (2019). The Role of Crowdfunding in Moving towards a Sustainable Society. Technological Forecasting and Social Change, 141, 66-73.

https://doi.org/10.1016/j.techfore.2018.12.011

DOI: 10.1016/.j.techfore.2018.12.011

* This version of the article has been accepted for publication and undergone full peer review but has not been through the copyediting, typesetting, pagination and proofreading process, which may lead to differences between this version and the publisher's final version AKA Version of Record.

Uploaded to CBS Research Portal: July 2019

(C) 2019. This manuscript version is made available under the CC-BY-NC-ND 4.0 license http://creativecommons.org/licenses/by-nc-nd/4.0/ 


\title{
The Role of Crowdfunding in Moving Towards a Sustainable Society
}

\begin{abstract}
Crowdfunding presents many opportunities for moving towards a sustainable society, with specific interest for sustainable entrepreneurs and innovators. In order to examine the potential role of crowdfunding in this context, we position this Special Issue (SI) within the larger stream of sustainability transitions literature, and in particular in relation to one of the field's key frameworks, i.e. the Multi-Level Perspective (MLP). We argue that crowdfunding represents a novel socio-technical practice with the potential of upscaling and transforming financial and potentially - sustainability regimes. This introductory article contains an overview of the articles, described by using the MLP typology. Some authors describe the role of crowdfunding in enabling user-producer and user-consumer interaction at an early stage; others focus on crowdfunding as a tool for user-legitimators and user-citizens. In terms of future research, the novelty of the phenomenon leaves a wide range of areas open for further research, with the current literature primarily focused on uncovering the antecedents of funding success and failure, something that is also apparent in this SI. To help the field move forward, we identify five areas as the most relevant for future research.
\end{abstract}




\section{Introduction}

In the face of increasingly important and complex grand challenges, organizations need to look for alternative ways of managing and supporting their activities (George et al. 2016). It is therefore essential to better understand how organizations are moving towards sustainable practices in terms, for example, of technology, business models and financing (Bocken et al. 2014; Chu \& Majumdar 2012; Vasileiadou et al. 2016). In that context, crowdfunding represents a growing source of alternative finance for a variety of both for- and non-profit ventures that is influencing how everything from personal loans to start-up investment is financed (Bone \& Baeck 2016). The process of crowdfunding itself has been commonly characterized by the successful "interaction between a facilitating organization (or platform), a variety of founder campaigns who seek financial support for their ideas and ventures, and a large dispersed "crowd" of individuals ("crowdfunders") who are enticed to invest, pledge, lend or donate to these ideas and ventures" (Nielsen 2018, p.1). Crowdfunding success is thus often dependent on a stranger's willingness to support other strangers for causes, products, or services that have not yet been realized and of which they have little direct oversight or control. Despite this, crowdfunding has emerged as an increasingly common source of finance for entrepreneurial (and other) projects seeking capital (Sorenson et al. 2016).

In $2013 / 14$ in the EU alone about $€ 2$.3billion were raised, filling a funding gap that is especially prevalent with entrepreneurs when seeking seed capital for an idea/inception or proof of concept/prototyping (World Bank 2013; European Commission 2015). The global crowdfunding industry reached $\$ 16.2$ billion in 2014 . In 2015 , the industry raised more than double and reached to $\$ 34.4$ billion (Massolution 2015). Spread across many types of funding models including donation, reward, lending, and equity, crowdfunding is expected to show an annual growth of 29\% between 2018 and 2022 (Statista 2018). The success of this phenomenon has also led to a steady stream of academic research seeking to unravel the antecedents of successful and unsuccessful initiatives (see Burtch et al. 2013; Mollick 2014; Belleflamme et al. 2014). The resulting insights include observations that crowdfunding appears to increase access to innovation finance, overcome geographical barriers, and in general enable a wider spectra of ideas and projects as compared to traditional sources of financing such as venture capital (see Sorenson \& Stuart 2001; Lehner \& Nicholls 2014; Agrawal et al. 2015). 
The potential of crowdfunding in supporting sustainable innovation ${ }^{1}$ and sustainable entrepreneurs $^{2}$ is also gaining both media (see Park 2012; Harte 2013; Thorpe 2014) and academic interest. However, academic contributions on this topic are still fragmented and sometimes contradictory and many issues are still far from being fully understood. Authors claiming potential for crowdfunding in the context of sustainability essentially rely on literature affirming that crowd investors' motivations are different from those of traditional financial investors (see Aitamurto 2011; Lehner 2013). As Lehner (2013, 2) states: "Crowd investors typically do not look much at collaterals or business plans, but at the ideas and core values of the firm". In other words, crowd investors participate because of non-material rewards such as the desire to support specific causes that may be close to their own hearts or the desire to help others (Gerber \& Hui 2013; Lehner \& Nicholls 2014; Allison et al. 2015). In this context, social and psychological factors may be equally or more important than strictly financial returns. This suggests that narrative may play a significant role in successful crowdfunding activities by establishing a convincing and compelling investment story (Manning \& Bejarano 2016). If we draw upon Lindenberg and Steg (2007), crowd investors could be assumed to be moved by altruistic or normative reasons, i.e. reasons meeting their (or their community's) moral or ethical norms, and select social ideas they deem worthy and needed (Lehner 2013). Vasileiadou et al. (2016) find that actually a combination of motivations may drive participation in crowdfunding campaigns ranging from hedonic goals (individuals want to improve the way they feel in a specific moment), gain goals (individuals aim at increasing or protecting their resources) or normative goals. This heterogeneity of motivations is important because, as stated elsewhere, initiatives relying only on ideological aims (i.e. normative goals) have a limited capacity to grow, as they have difficulties linking to a wider range of actors and scaling up (Seyfang \& Longhurst 2013; Smith \& Seyfang 2013).

According to Calic and Mosakowski (2016), individuals engaged in crowdfunding generally share a 'loose ideology'. Different crowdfunding platforms may have different loose ideologies, depending on the mission of the platform and the values and beliefs of individuals

\footnotetext{
${ }^{1}$ Sustainable innovation is understood as an advance in a product, service, or process system that offers an improved or the same economic performance with fewer externalities in the form of social and environmental hazards (Halme \& Laurila 2009; Bos-Brouwers 2010).

2 The sustainable entrepreneur is an individual or group of individuals who have recognized, developed, and exploited an opportunity to "bring into existence future goods and services with economic, social and ecological gains" (Belz \& Binder 2017, p.2). These product or service ideas emerge either through invention by users based on their own needs or by individuals recognizing a product or service opportunity to solve either an ecological and/or social problem (Cohen \& Winn 2007).
} 
frequenting the platform. For example, Calic and Mosakowski (2016) argue that, given the demography of crowdfunders on Kickstarter, the loose ideology of that platform is supportive of a sustainability orientation. Furthermore, crowdfunding involves not only family and friends but also backers ${ }^{3}$ who are geographically and socially distant from the entrepreneurs they support and therefore backers cannot rely solely on social capital to reduce information asymmetries. Beyond claiming potential for crowdfunding in the context of sustainability (Bartenberger \& Leitner 2013; Bonzanini et al. 2015; Vasileiadou et al. 2016; Lam \& Law 2016), some conceptual and empirical works suggest a positive relationship between environmental or sustainability orientation and the likelihood of success of crowdfunding projects (Lehner 2013; Calic \& Mosakowski 2016). For example, Calic and Mosakowski (2016) find that a sustainability orientation positively affects funding success of crowdfunding projects, and that this relationship is partially mediated by project creativity and third-party endorsements. However, conversely Hörisch (2015a, 2018) does not observe any positive connection between sustainability orientation (specifically environmental) and crowdfunding success. His results are in line with part of the crowdfunding literature claiming that crowdfunders are likely to act similarly to conventional financiers for example in pursing prospects of financial return (see Ordanini et al. 2011; Moss et al. 2015) or early access to products at reduced premium (Belleflamme et al., 2010).

This special issue is interested in contributing to this growing field in its infancy especially by exploring the opportunities it presents for sustainable entrepreneurs and innovators. Such a focus on these actors is due to the fact that they are increasingly recognized as fundamental for changing our current consumptive and productive patterns, which continue to challenge the planetary boundaries of our planet (Rockström et al. 2009; IPCC 2014). Challenges like climate change, loss of biodiversity, and interference with the nitrogen cycles have already crossed their "safe operating space" (see Rockström et al. 2009) and thus require "factor 10 or more improvements in environmental performance, which can only be realized by deep-structural changes in transport, energy, agri-food and other systems" (Geels 2011). Incremental improvements in technology are thus seen as insufficient in alleviating these systematic issues and experts are thus increasingly calling for larger "socio-technical" changes to tackle the threats posed to our planet's ecological boundaries (Tukker et al. 2008; Geels 2010; IPCC

\footnotetext{
${ }^{3}$ Backer refers to someone who contributes to a reward-based crowdfunding campaign (like those on Kickstarter).
} 
2014). These larger shifts in the "socio-technical" regime often spearheaded by niche innovators - single users, entrepreneurs, and start-ups - rather than incumbents as they are seen to operate in "protected spaces" where there are special demands and thus a greater willingness to support emerging innovations (Kemp \& Rotmans 2004; Geels 2010; 2011). Niche innovators are thus more likely to work on radical innovations that deviate from the "lockedin" nature of the current regime (Unruh 2000; Geels 2010). If crowdfunding could thus enable more niche innovation actors like sustainable entrepreneurs it would be a welcome development.

\section{Background}

In order to examine the potential role of crowdfunding in financing sustainable entrepreneurship we must firstly examine how the role of the consumers -or end-users ${ }^{4}$ as they will be referred to from this point- within innovation has undergone a marked shift in recent years. From being viewed as nearly passive recipients of producer-made goods and services, they turned to be active participants in the entire innovation process (von Hippel 2005; Bogers et al. 2010). This increasing role of the end-users within sustainable innovation has subsequently also garnered increased attention from the sustainability field especially as they are conceived as niche innovators able to create significantly different innovation as they operate in protected spaces outside the locked-in nature of the existing social-technical regime (Geels 2010; Belz 2013). We argue that crowdfunding represents a novel socio-technical practice with the potential of upscaling and transforming financial and potentially sustainability regimes by enabling significant levels of user-producers and user-consumers interaction. Additionally, as the papers in this SI informed us, it may also serve to provide further legitimacy for sustainable entrepreneurial endeavors and citizen action. Thus, according to Schot et al.'s (2016) typology, crowdfunding may enable not only interaction between userproducers and user-consumers, but also it can act as a tool for user-legitimators and usercitizens. Figure 1 serves to position our SI within the larger stream of sustainability transitions literature, and in particular in relation to one of the field's key frameworks i. e. the Multi-Level Perspective (MLP) (Geels, 2002) and to show where crowdfunding may play a role (see the coloured boxes).

\footnotetext{
${ }^{4}$ End-user and user are used interchangeably
} 
Figure 1. Positioning the SI

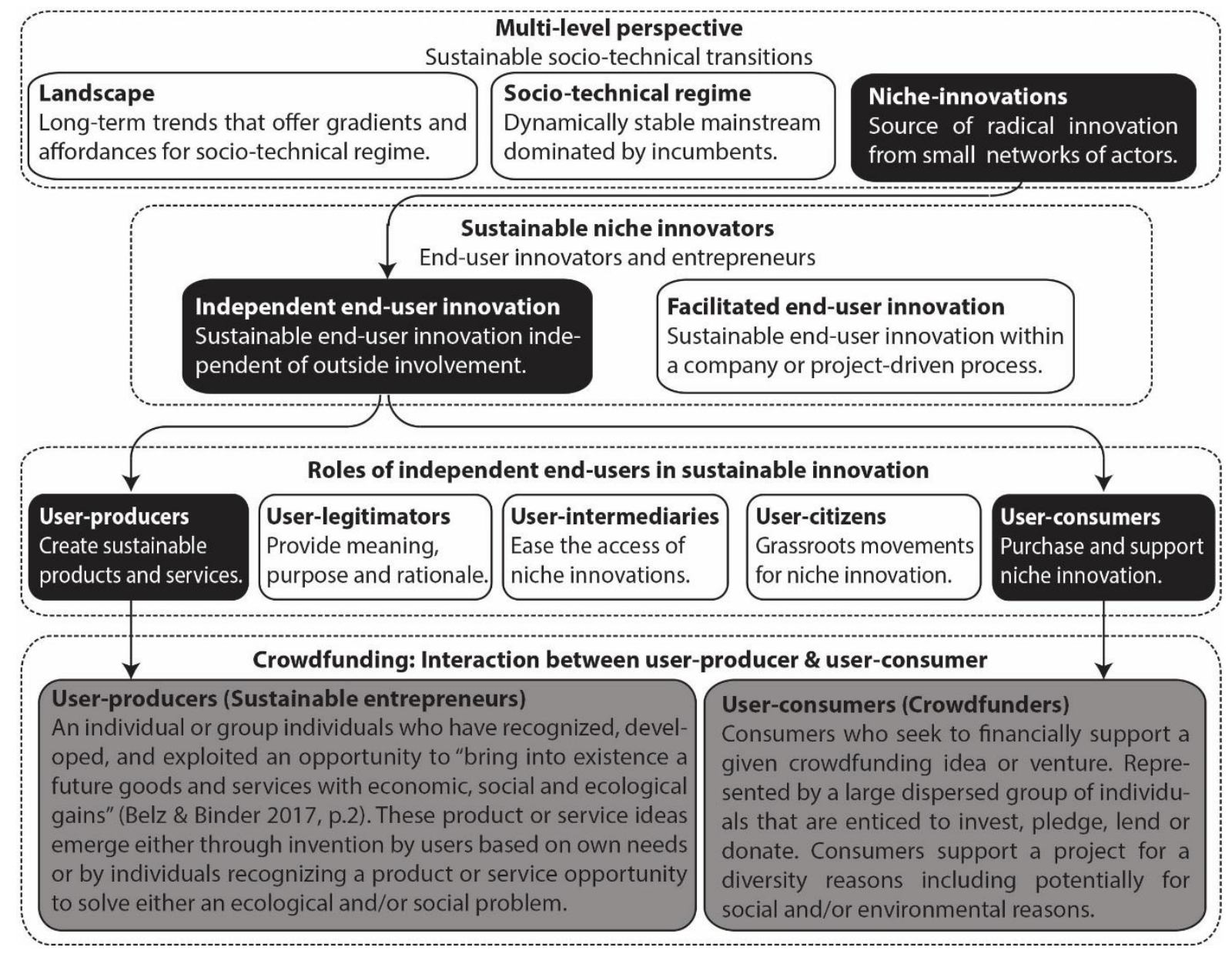

Source: Adapted from Nielsen (2017) original figure

\subsection{The multi-level perspective}

The MLP conceptualises the process of socio-technical transitions (Geels \& Schot 2007) as a dynamically stable interaction between landscape, regime and niche. These transitions are characterized not only by technological changes but also by shifts in other practices that typically act to lock-in change. Lock-in results from regime level pressures - for example existing regulation, infrastructure, and user preferences - that act to stabilise against change (Unruh 2000; Geels 2002). The MLP thus proposes that radical change is dependent on niche innovations that emerge from small networks of actors, such as end-users, entrepreneurs and start-ups, who operate in protected space where special demands insulate novel ideas and prototypes. However, as their innovations challenge the existing locked-in regime they nonetheless inhabit a precarious space. In the context of sustainable entrepreneurship this is evident challenge as their sustainable solutions are often not easily integrated into a current regime (Geels 2010). Given that the majority of business-related literature has focused on large 
incumbents, the MLP could be seen as call to focus on smaller agents of change (Hörisch 2015b; Wainstein \& Bumpus 2016).

\subsection{Niche innovators and the roles of independent end-users in sustainable innovation}

Having established the central role of niche innovators in driving sustainable socio-technical transitions, we shall now seek to expand on who these niche innovators are. Firstly, these niche innovators are defined - in line with a large stream of the innovation literature (e.g. the work of von Hippel $(1976 ; 2005)$ ) - as end-user(s) and thus "the end-consumer (or groups of consumers) of a given product or service" (Nielsen et al. 2016). We should note that end-users can also play a significant role in firm-driven open innovation processes (Chesbrough et al. 2014; Bogers et al. 2018), however, for this SI, we are focused primarily on independent enduser action rather than end-user innovation within a facilitated process, for example, within a firm. Utilizing Schot et al.'s (2016) adaption of the MLP from a user perspective we can thus conceive that the user can take on a number of roles in driving a niche innovation into the regime. These roles are categorized as user-producers, user-legitimators, user-intermediaries, user-citizens and user-consumers. The user supports the transition of the specific niche innovation towards ultimately replacing the existing regimes' technology, rules, and practices starting from the early start-up phase through acceleration and finally the stabilization phase. As illustrated in Figure 2, the respective roles of the user depends where they are found on the respective three phases. For example, the start-up phase is brought on by a destabilization of the current socio-technical regime due to shifts in landscape pressures, for example, climate change. These pressures from the landscape level undermine elements within the sociotechnical regime, which in turn stimulates experimentation and invention by user-producers. Alongside these user-producers, a number of user-legitimators act by providing meaning, purpose, and rationale for these activities. "For example, from the 1970s the limits-to-growth narrative has provided meaning to the development of renewables and helped to shape expectations about their future" (Schot et al. 2016, p.4). The user-producers and/or usersturned-entrepreneurs thus provide possible alternative product and service solutions brought on by a shift at landscape level, whereas user-legitimators act to create a common narrative within the niche while simultaneously questioning the socio-technical regime's ability to deal with these challenges (for example climate change). 
Figure 2. MLP and the role of the user

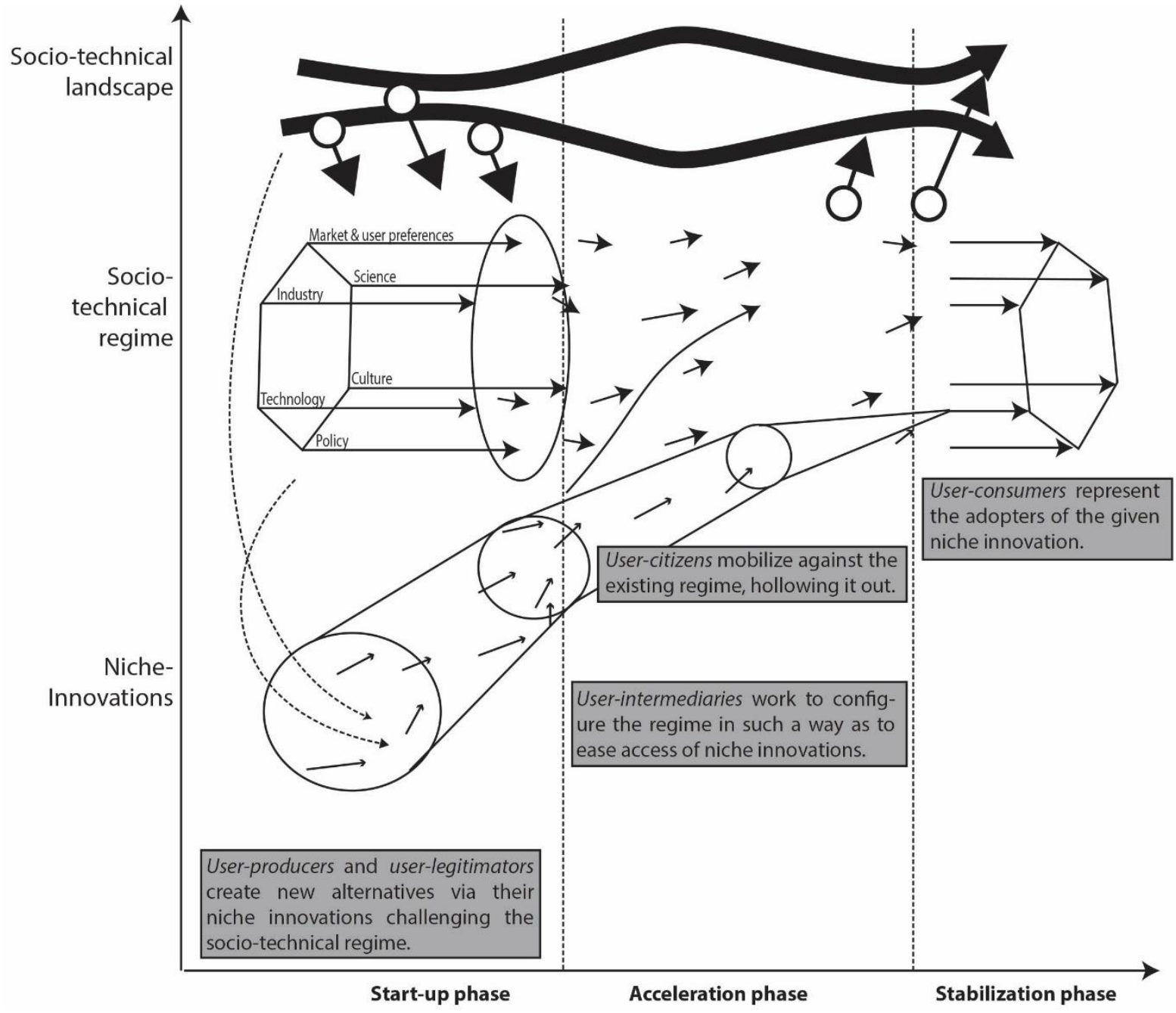

Source: Adapted from Schot et al.'s (2016) original figure

During the acceleration phase, user-intermediaries and user-citizens act to create a space in which niche innovation can take hold. User-intermediaries - representing national or regional organizations aimed at promoting sustainable causes - work to configure the socio-technical regime and emergent technologies in such a way, that they ease the access of the niche innovations into the regime. User-intermediaries align themselves with likeminded firms, governments, NGOs, and individual user-citizens in efforts to achieve their goals. The usercitizen is, in turn, represented by grassroots movements which "engage in regime-shift politics, lobbying for a particular niche and against the regime (or other niches)" (Schot et al. 2016, p.4) and effectively acting as mainstream niches in the eyes of user-consumers. Finally, userconsumers represent the adopters of the given niche innovation. Ideally, as the niche innovation is adopted and further developed, it slowly replaces the previous socio-technical system and 
creates a new stabilized socio-technical regime (i.e. new infrastructure, legislation and user practices). The emergence of steam-powered shipping, for example, was spurred on by their ability to operate in niche areas and as they developed increasingly spreading to other domains (Geels 2002).

\subsection{Crowdfunding: Interaction between user-producer and user-consumer}

In utilizing Schot et al.'s (2016) user typology we note that crowdfunding -with its direct interaction between user-producers (the entrepreneur) and user-consumers (the crowdfunder)represents a unique constellation that arguably is not well-captured in the Schot et al.'s (2016) user typology. The user-consumers within crowdfunding not only passively adopt userproducer innovations but also actively engage in enabling product or service innovation. This active role thus requires that the individual crowdfunders not only have interest in the given product or service, but are also willing to trust that campaign founders can deliver. From a business cycle perspective, in the crowdfunding process the consumer is therefore active and fundamental to the development of the product or service, while in traditional business model the product or service is realized without consumer engagement. The example of crowdfunding thus shows that the user-consumer's role within any transition process is not only enacted within the stabilization phase as proposed by Schot et al., (2016), but it can also be relevant in the initial start-up phase. Furthermore, user-consumers may express their opinions on sustainability issues (not only by means of comments directly on the crowdfunding platform but also by means of interaction mechanisms enacted in external social networks and virtual communities connected to crowdfunding campaigns). Thus, they can play the role of userlegitimators. Literature emphasizes that crowdfunders, even though they are free to offer financial support without necessarily personally engage in the project, often provide suggestions, feedbacks and promotions to make sure the project succeed (Hui et al., 2014; Ordanini et al, 2011; Yoo and Choe, 2014). In addition, the literature claims that crowdfunding provides an ecosystem facilitating broader resource exchange between stakeholders (Lambert and Schwienbacher 2010). This potentially facilitates the collective development of a business plan or other knowledge exchange not found in venture capital, which more often, especially in the screening phase, judges rather than co-creates the business plan (Frydrych et al. 2014). If we assume that sustainable consumer effort is made of not only boycott and buycott practices but also discursive actions and expression of opinions about sustainability issues in a variety of communicative efforts and venues (Micheletti et al. 2012), crowdfunding may play an even 
more relevant role. Indeed, Koçer (2014) claims that crowdfunding campaigns, when circulate through social media, may forge the social causes to which they refer.

Understanding whether and how sustainable entrepreneurs tap into this growing source of alternative finance thus presents a unique opportunity for sustainable entrepreneurs, who otherwise face a myriad of challenges not least the locked-in nature of the current regime which they intend to change (Unruh 2000; Geels 2002). One consequence of this lock-in is a constrained funding environment for sustainable entrepreneurs, especially in the early seed funding stage. Sustainable entrepreneurs with their social and environmental goals are often perceived as a less attractive investments compared to traditional entrepreneurial ventures in the early stage of seed funding (Choi \& Gray 2008). They are thus often relegated to a relatively narrow set of funding opportunities. In such cases crowdfunding may fill the funding gaps that are especially prevalent for entrepreneurs when seeking seed finance as illustrated in Figure 3 (World Bank 2013; Sorenson et al. 2016).

Figure 3. Where crowdfunding fits on the innovation funding lifecycle

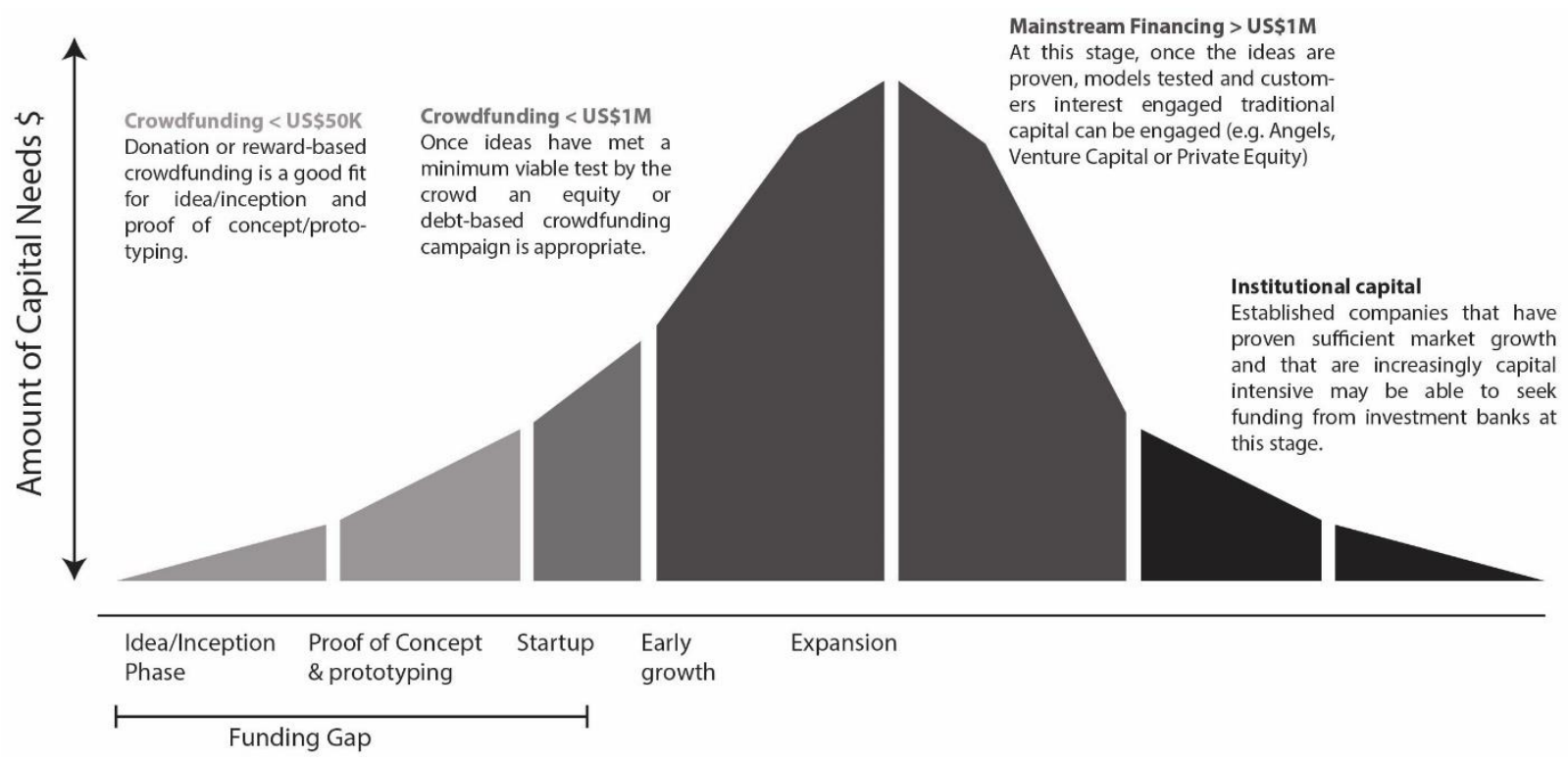

Source: Revised figure based World Bank $(2013, p .16)^{5}$

\footnotetext{
${ }^{5}$ It should be noted that while respectively donation- and reward-based crowdfunding and loan- and equity-based crowdfunding are placed within the same respective two categories by the World Bank report "Crowdfunding's Potential for the Developing World" (World Bank 2013), they are significantly different in terms of average amount of money raised. On average, successful donation-based campaigns raise $€ 2,938$, while reward-based campaigns on average make close to $\$ 8,000$ US (approx. $€ 7,400$ ) (Mollick 2014; Nielsen et al. 2017). Successful loan-based campaign raises between $€ 7,082$ and $€ 79,132$ depending on whether they are business or individual loans and whether they are secured or unsecured. In comparison successful equity-based campaigns raise on average 504,832 € (European Commission 2015).
} 


\section{Articles in this SI}

We have proposed that crowdfunding represents a novel socio-technical practice with the potential of upscaling and transforming financial and potentially sustainability regimes due its ability to create a direct interaction between user-producers and user-consumers at an early stage. This is exemplified by the paper by Chaney (2018) who argues that crowdfunding creates an inverted agency relationship between the company and consumers that empowers consumers to serve as market gatekeepers.

However, on reading the seven papers in this SI it also became apparent that crowdfunding also enables other user roles apart from user-producers and user-consumers interactions. Crowdfunding also allows consumers to take-on the role of user-citizens and user-legitimators. For example, the paper by Laurell et al. (2018), shows that crowdfunding enables consumers to act as user-citizens by allowing them spread the campaigns message via their social media, thus acting as promoters of sustainable products, services and practices. This may spillover into enabling greater trust in sustainable products and thus be a form of user-legitimization. Wehnert et al. (2018) illustrate how crowdfunders may legitimize sustainable products as successful crowdfunding affects trust in sustainable product features.

Our SI opens with the paper "A principal-agent perspective on consumer co-production: Crowdfunding and the redefinition of consumer power", written by Chaney (2018) and is focused on the unique interaction between user-producer and user-consumers. The study reveals through a series of in-depth interviews with campaign founders that crowdfunding represents a unique form of co-production. Specifically, the reliance on consumers for funding empowers them beyond traditionally conceived passive receivers of market goods and instead transform them into market gatekeepers as they collectively decide whether the product will be launched on the market or not. Thus, in crowdfunding an argued inverted agency relationship is created between the user-producer and user-consumers with user-consumers having some ideas about products to put on the market as principals and user-producers giving shape to these ideas as agents.

The paper "Green Oriented Crowdfunding Campaigns: Their Characteristics and Diffusion in Different Institutional Settings", written by Butticè et al. (2018), focuses on user-producers and shows that they have a higher propensity to launch their green initiatives on crowdfunding platforms in countries with a limited environmental sustainability orientation. This means that 
in countries where there is a lack of sustainability policies and regulations (e.g. public subsidies) as well as sustainability-oriented shared values and beliefs, user-producers cannot rely on conventional financing channels and therefore they resort to crowdfunding. Such a finding has important implications regard the role that public actors can play in different institutional settings to help user-producers to create sustainable products and services.

The paper "Sustainability in Equity Crowdfunding" by Vismara (2018) focuses on userconsumers and user-producers interaction and finds that - in equity crowdfunding sustainability orientation does not increase the chances of success or of engaging professional investors but attracts a higher number of user-consumers (i.e. crowd/not professional investors). The latter, absent in other entrepreneurial financial markets, do not generally have prior experience in financing and value the sustainability-orientation of companies. They make decision with a community logic rather than a market logic, typical of professional investors. While in market logic, expected high monetary returns are the main logic for support, in community logic also projects' non-monetary aspects, such as the attention to community advancement and the potential of "bettering the world" are considered.

The paper "Do Crowdfunding Returns Reward Risk? Evidences from Clean-tech Projects" by Bento et al. (2018) provides insights on a specific aspect of user-consumers i.e. their sensibility to technological risks. It is well known that technological risk increases the potential of losses or no profits for the funders. Thus, it is typically associated with higher expected returns to compensate investors for the higher risks. Results reported by the authors are in contrast with this tenet: platforms do not seem to price correctly the technological risk of the projects and concomitantly user-consumers are accepting to take additional risks for the same reward. This behavior may be driven by the fact that user-consumers evaluate clean-tech crowdfunding projects not solely for the associated financial returns but also for non-financial considerations such as the environmental and social impact.

The paper "Assessing the interplay between crowdfunding and sustainability in social media" by Laurell et al. (2018) takes on an exciting approach for studying which sustainability-oriented dimensions are integrated within the public discourse on crowdfunding in social media. Employing a social media analysis methodology, they note that the discourse around sustainability-oriented crowdfunding remains predominated by professional actors, while the general public discourse on crowdfunding is sparsely touched by sustainable themes. Thus 
while user-consumers may show a greater willingness at time to engage in sustainabilityoriented campaigns, as for example Vismara (2018) shows, they do not actively promote it through their social media channels. The limited public discourse around crowdfunding - those that we could consider as user-citizens and user-legitimators - thus remains concentrated around few professional individuals.

The second to last paper in our SI is the paper "In Crowdfunding We Trust? Investigating Crowdfunding Success as a Signal for Enhancing Trust in Sustainable Product Features" by Wehnert et al. (2018) who employ a between-group experiment to observe how crowdfunded products effect consumer perceptions. They find that successfully funded crowdfunded campaigns has an influence on product perceptions and on the credibility of sustainability attributes. These findings are especially exciting as it shows that crowdfunding may not only serve to enable sustainability-oriented products, but may (in various degrees, as you will read) also influence the perceived level of trust and perhaps uptake of the given product.

The paper "Understanding the Crowdfunding Phenomenon and its Implications for Sustainability" by Messeni Petruzzelli et al. (2018) is a conceptual paper and it closes our SI by providing another framework to interpret the issue of crowdfunding and sustainability. The paper focuses on five key dimensions, respectively project creators (i.e. user-producers), backers (i.e. user-consumers), campaigns, crowdfunding platforms, and outcomes of the crowdfunding campaigns. They re-interpret the general findings available in the crowdfunding literature according to their five-dimensional framework and adapt them to the specific context of sustainability, by formulating a set of propositions.

\section{Where do we go from here?}

In terms of future research, the novelty of the phenomenon of crowdfunding leaves a wide range of areas open for future research, with the current literature primarily focused on uncovering the antecedents of funding success and failure, something that is also apparent in this SI. We propose five topics as the most relevant for future research.

Firstly, we need more studies to focus on how various models of crowdfunding may differently influence user-consumers' motivations and pledging behaviors. The simple fact that one is donating, pledging, lending and investing could arguably influence behavior in significant way. Dushnitsky \& Fitza (2018), for example, finds that the antecedents of success in one platform 
do not replicate well in other platforms. This would suggest that the platform alone strongly influences the factors associated with success. Secondly, it would be a worthwhile pursuit to explore the commonly noted differences between user-consumers (i.e. crowd-investors) and professional investors (see for example Gerber \& Hui 2013; Lehner 2013 and Vismara, 2018 in this SI) as the proposition itself rests on a arguably weak empirical footing. The present contribution therefore proposes that future research should not only seek to account for variation across the different models of crowdfunding but ideally also uncover whether (and how) they truly are different from, for example, professional investors, angel investors, and venture capitalists. Sorenson et al. (2016) have shown that crowdfunding leads to expanded access to innovation finance as compared to venture capital, but what else? From a sustainability perspective, this is especially pertinent in order to understand how the various models of crowdfunding can be best leveraged to support sustainable entrepreneurship and innovation.

Thirdly, more research is needed in order to explore for which ventures crowdfunding is a suitable financing alternative. For example, it is still commonly assumed that crowdfunding reflects a last resort avenue for financing (see for example what Butticè et al. (2018) write in this SI); however as the phenomenon continues to grow rapidly it may increasingly become one of a host of funding options available for user-producers rather than simply the final option after all other alternatives have been exhausted (Ahlers et al. 2015). In addition to this, the potentially positive and negative spillover effects of successful and unsuccessful crowdfunding could also be explored with relation to future success with venture capitalists or other innovation financiers.

Fourthly, the SI also notes that there is a need for significantly more research on the userproducers who have achieved funding success and how they translate this into a (un)successful business model. Indeed, there is a growing interest in sustainable business models, in terms of both archetypes and processes (Bocken et al, 2014, 2019; Sund et al, 2016), and the role of financing in general and crowdfunding in particular will be important to explore. Similarly, in the face of complex grand challenges, it will be useful to further explore how and under which conditions crowdfunding can help to support sustainable solutions through open innovation practices (Afuah \& Tucci 2012; Bogers et al 2017; Chesbrough \& Bogers 2014; George et al. 2016). 
Fifthly, the study of role of the platform (or intermediary) in shaping behavior remains largely untouched within the literature, which is unfortunate given their significant role in enabling and defining the "rules of the game" (Martini et al. 2013). Finally, there is an overwhelming amount of research within the field that builds upon quantitative analysis of large datasets that while contribute greatly to our knowledge of the phenomenon could also be supplemented with more in-depth qualitative methods. As it is also evident in this SI, the quantitative approach truly dominates the field, while rigorous qualitative studies could add a lot to our understanding of the underlying causal mechanisms, processes and dynamics.

\section{Acknowledgements}

We would like to thank all the authors for the work they have done on writing up the articles for this SI and on modifying them based on the reviewers' comments. We are also grateful to the Editor-in-Chief, Professor Fred Phillips, for his support, and the whole Editorial Staff for their insightful and practical advice. Thanks also go to the many reviewers for their valuable contributions in terms of both efficiency and effectiveness.

\section{References}

Afuah, A., \& Tucci, C. L. 2012. Crowdsourcing as a solution to distant search. Academy of Management Review, 37(3), pp 355-375. Available at doi:10.5465/amr.2010.0146

Agrawal, A., Catalini, C. \& Goldfarb, A., 2015. Crowdfunding: Geography, Social Networks, and the Timing of Investment Decisions. Journal of Economics \& Management Strategy, 24(2), pp.253-274. Available at: http://dx.doi.org/10.1111/jems.12093.

Ahlers, G.K.C.C. et al., 2015. Signaling in Equity Crowdfunding. Entrepreneurship Theory and Practice, 39(4), pp.955-980. Available at: http://dx.doi.org/10.1111/etap.12157.

Aitamurto, T., 2011. The impact of crowdfunding on journalism. Journalism Practice, 5(4), pp.429-445. Available at: https://doi.org/10.1080/17512786.2010.551018.

Allison, T.H. et al., 2015. Crowdfunding in a Prosocial Microlending Environment: Examining the Role of Intrinsic Versus Extrinsic Cues. Entrepreneurship Theory and Practice, 39(1), pp.53-73. Available at: http://dx.doi.org/10.1111/etap.12108.

Bartenberger, M. \& Leitner, P., 2013. Crowdsourcing and Crowdfunding: Approaches to Foster Social Innovation. In Proceedings of the IADIS International Conference Web Based Communities and Social Media. pp. 81-85.

Belleflamme, P., Lambert, T. \& Schwienbacher, A., 2014. Crowdfunding: Tapping the right 
crowd. Journal of Business Venturing, 29(5), pp.585-609. Available at: http://www.sciencedirect.com/science/article/pii/S0883902613000694.

Belz, F.-M., 2013. Shaping the future: Sustainable innovation and entrepreneurship. Social Business, 3(4), pp.311-324. Available at: 10.1362/204440813X13875569154028.

Belz, F.M. \& Binder, J.K., 2017. Sustainable Entrepreneurship: A Convergent Process Model. Business Strategy and the Environment, 26(1), pp.1-17. Available at: http://dx.doi.org/10.1002/bse.1887.

Bento, N., Gianfrate, G. \& Groppo, S.V., 2018. Do crowdfunding returns reward risk? Evidences from clean-tech projects. Technological Forecasting and Social Change. Available at: http://www.sciencedirect.com/science/article/pii/S0040162517310260.

Bogers, M., Afuah, \& Bastian, B., 2010. Users as Innovators: A Review, Critique, and Future Research Directions. Journal of Management, 36(4), pp.857-875. Available at: http://jom.sagepub.com/cgi/doi/10.1177/0149206309353944.

Bogers, M., Chesbrough, H. \& Moedas, C., 2018. Open Innovation: Research, Practices, and Policies. California Management Review, 60(2), pp.5-16. Available at: https://doi.org/10.1177/0008125617745086.

Bone, J. \& Baeck, P., 2016. Crowdfunding good causes, London. Available at: https://www.nesta.org.uk/sites/default/files/crowdfunding_good_causes-2016.pdf.

Bonzanini, D., Giudici, G. \& Patrucco, A., 2015. The Crowdfunding of Renewable Energy Projects. In Handbook of Environmental and Sustainable Finance. Cambridge, MA: Academic Press.

Bos-Brouwers, H.E.J., 2010. Corporate sustainability and innovation in SMEs: Evidence of themes and activities in practice. Business Strategy and the Environment, 19(7), pp.417435. Available at: http://dx.doi.org/10.1002/bse.652.

Burtch, G., Ghose, A. \& Wattal, S., 2013. An Empirical Examination of the Antecedents and Consequences of Contribution Patterns in Crowd-Funded Markets An Empirical Examination of the Antecedents and Consequences of Contribution Patterns in CrowdFunded Markets. Information Systems Research, 24(3), pp.499-519.

Calic, G. \& Mosakowski, E., 2016. Kicking Off Social Entrepreneurship: How A Sustainability Orientation Influences Crowdfunding Success. Journal of Management Studies, 53(5), pp.738-767. Available at: http://dx.doi.org/10.1111/joms.12201.

Chaney, D., 2018. A principal-agent perspective on consumer co-production: Crowdfunding and the redefinition of consumer power. Technological Forecasting and Social Change. Available at: http://www.sciencedirect.com/science/article/pii/S0040162517307710. 
Chesbrough, H.W., Vanhaverbeke, W. \& West, J., 2014. New Frontiers in Open Innovation, Oxford: Oxford University Press.

Choi, D.Y. \& Gray, E.R., 2008. The venture development processes of "sustainable" entrepreneurs. Management Research News, 31(8), pp.558-569.

Cohen, B. \& Winn, M.I., 2007. Market imperfections, opportunity and sustainable entrepreneurship. Journal of Business Venturing, 22(1), pp.29-49. Available at: http://www.sciencedirect.com/science/article/pii/S0883902605000571.

Dushnitsky, G. \& Fitza, M.A., 2018. Are we missing the platforms for the crowd? Comparing investment drivers across multiple crowdfunding platforms. Journal of Business Venturing Insights, 10, p.e00100. Available at: http://www.sciencedirect.com/science/article/pii/S2352673418300921.

European Commission, 2015. Crowdfunding: Mapping EU Markets and Events Study, Available at: https://staging.crowdsurfer.com/info/ec/.

Frydrych, D. et al., 2014. Exploring entrepreneurial legitimacy in reward-based crowdfunding. Venture Capital, 16(3), pp.247-269. Available at: https://doi.org/10.1080/13691066.2014.916512.

Geels, F.W., 2010. Ontologies, socio-technical transitions (to sustainability), and the multilevel perspective. Research Policy, 39(4), pp.495-510. Available at: http://www.sciencedirect.com/science/article/pii/S0048733310000363.

Geels, F.W., 2002. Technological transitions as evolutionary reconfiguration processes: a multi-level perspective and a case-study. Research Policy, 31(8-9), pp.1257-1274. Available at: http://www.sciencedirect.com/science/article/pii/S0048733302000628.

Geels, F.W., 2011. The multi-level perspective on sustainability transitions: Responses to seven criticisms. Environmental Innovation and Societal Transitions, 1(1), pp.24-40. Available at: http://www.sciencedirect.com/science/article/pii/S2210422411000050.

Geels, F.W. \& Schot, J., 2007. Typology of sociotechnical transition pathways. Research Policy, 36(3), pp.399-417.

Gerber, E.M. \& Hui, J., 2013. Crowdfunding: Motivations and Deterrents for Participation. ACM Transactions on Computer-Human Interaction, 20(6), pp.34-32.

Halme, M. \& Laurila, J., 2009. Philanthropy, Integration or Innovation? Exploring the Financial and Societal Outcomes of Different Types of Corporate Responsibility. Journal of Business Ethics, 84(3), pp.325-339. Available at: http://dx.doi.org/10.1007/s10551008-9712-5.

Harte, M., 2013. Climate Change This Week: Solar CrowdFunding, Wild Arctic Times, and 
More! Huffington Post.

von Hippel, E., 2005. Democratizing Innovation, Cambridge (MA): MIT Press.

von Hippel, E., 1976. The dominant role of users in the scientific instrument innovation process. Research Policy, 5(3), pp.212-239.

Hörisch, J., 2015. The Role of Sustainable Entrepreneurship in Sustainability Transitions: A Conceptual Synthesis against the Background of the Multi-Level Perspective. Administrative Sciences, 5(4), pp.1-15. Available at: https://econpapers.repec.org/RePEc:gam:jadmsc:v:5:y:2015:i:4:p:286-300:d:58982.

IPCC, 2014. Fifth Assement Report of the Intergovernmental Panel on Climate Change, Geneva.

Kemp, R. \& Rotmans, J., 2004. Managing the transition to sustainable mobility. In B. Elzen, F. Geels, \& K. Green, eds. System innovation and the transition to sustainability: theory, evidence and policy. Cheltenham: Edward Elgar Publishing, pp. 137-167.

Koçer, S., 2014. Social business in online financing: Crowdfunding narratives of independent documentary producers in Turkey. New Media \& Society, 17(2), pp.231-248. Available at: https://doi.org/10.1177/1461444814558913.

Lam, P.T.I. \& Law, A.O.K., 2016. Crowdfunding for renewable and sustainable energy projects: An exploratory case study approach. Renewable and Sustainable Energy Reviews, 60, pp.11-20. Available at: http://www.sciencedirect.com/science/article/pii/S1364032116000769.

Laurell, C., Sandström, C. \& Suseno, Y., 2018. Assessing the interplay between crowdfunding and sustainability in social media. Technological Forecasting and Social Change. Available at: http://www.sciencedirect.com/science/article/pii/S0040162517308600.

Lehner, O.M., 2013. Crowdfunding social ventures: a model and research agenda. Venture Capital, 15(4), pp.289-311. Available at: http://dx.doi.org/10.1080/13691066.2013.782624.

Lehner, O.M. \& Nicholls, A., 2014. Social finance and crowdfunding for social enterprises: A public-private case study providing legitimacy and leverage. Venture Capital, 16(3), pp.271-286. Available at: 10.1080/13691066.2014.925305.

Lindenberg, S. \& Steg, L., 2007. Normative, Gain and Hedonic Goal Frames Guiding Environmental Behavior. Journal of Social Issues, 63(1), pp.117-137. Available at: https://doi.org/10.1111/j.1540-4560.2007.00499.x.

Manning, S. \& Bejarano, T.A., 2016. Convincing the crowd: Entrepreneurial storytelling in crowdfunding campaigns. Strategic Organization . Available at: 
http://soq.sagepub.com/content/early/2016/05/18/1476127016648500.abstract.

Martini, A., Massa, S. \& Testa, S., 2013. The firm, the platform and the customer: A "double mangle" interpretation of social media for innovation. Information and Organization, 23(3), pp.198-213. Available at: http://www.sciencedirect.com/science/article/pii/S1471772713000249.

Massolution, 2015. O15CF Crowdfunding Industry Report, Available at: http://reports.crowdsourcing.org/index.php?route=product/product\&product_id=54.

Messeni Petruzzelli, A. et al., 2018. Understanding the crowdfunding phenomenon and its implications for sustainability. Technological Forecasting and Social Change. Available at: http://www.sciencedirect.com/science/article/pii/S0040162517313690.

Micheletti, M., Stolle, D. \& Berlin, D., 2012. Habits of Sustainable Citizenship: The Example of Political Consumerism. In COLLeGIUM: Studies across Disciplines in the Humanities and Social Sciences 12.

Mollick, E., 2014. The dynamics of crowdfunding: An exploratory study. Journal of Business Venturing, 29(1), pp.1-16. Available at: http://www.sciencedirect.com/science/article/pii/S088390261300058X.

Moss, T.W., Neubaum, D.O. \& Meyskens, M., 2015. The Effect of Virtuous and Entrepreneurial Orientations on Microfinance Lending and Repayment: A Signaling Theory Perspective. Entrepreneurship Theory and Practice, 39(1), pp.27-52. Available at: http://dx.doi.org/10.1111/etap.12110.

Nielsen, K.R., 2018. Crowdfunding through a partial organization lens - The co-dependent organization. European Management Journal.

Nielsen, K.R., Gallemore, C. \& Jespersen, K., 2017. Crowdfunding and institutional change, Working Paper. Copenhagen - Copenhagen Business School.

Nielsen, K.R., Reisch, L.A. \& Thøgersen, J., 2016. Sustainable user innovation from a policy perspective : A systematic literature review. Journal of Cleaner Production, 133(613194), pp.65-77. Available at: http://dx.doi.org/10.1016/j.jclepro.2016.05.092.

Ordanini, A. et al., 2011. Crowdfunding: transforming customers into investors through innovative service platforms. Journal of Service Management, 22(4), pp.443-470. Available at: http://dx.doi.org/10.1108/09564231111155079.

Park, A., 2012. Crowdfunding a cure: the sick are getting strangers to pay their medical bills. Time, 180(23), p.22.

Rockström, J. et al., 2009. A safe operating space for humanity. Nature, 461(7263), pp.472475. Available at: http://dx.doi.org/10.1038/461472a. 
Schot, J., Kanger, L. \& Verbong, G., 2016. The roles of users in shaping transitions to new energy systems. Nature Energy, 1, p.16054. Available at: http:https://dx.doi.org/10.1038/nenergy.2016.54.

Seyfang, G. \& Longhurst, N., 2013. Desperately seeking niches: Grassroots innovations and niche development in the community currency field. Global Environmental Change, 23(5), $\quad$ pp.881 $\quad$ - $891 . \quad$ Available at: http://www.sciencedirect.com/science/article/pii/S095937801300037X.

Smith, A. \& Seyfang, G., 2013. Constructing grassroots innovations for sustainability. Global Environmental Change, 23(5), pp.827-829.

Sorenson, O. et al., 2016. Expand innovation finance via crowdfunding. Science, 354(6319), p.1526 LP-1528. Available at: http://science.sciencemag.org/content/354/6319/1526.abstract.

Sorenson, O. \& Stuart, T.E., 2001. Syndication Networks and the Spatial Distribution of Venture Capital Investments. American Journal of Sociology, 106(6), pp.1546-1588. Available at: http://www.jstor.org/stable/10.1086/321301.

Statista, 2018. Crowdfunding - Statistics \& Facts. Statista. Available at: https://www.statista.com/topics/1283/crowdfunding/ [Accessed April 24, 2018].

Thorpe, D., 2014. Crowdfunding success stories include $\$ 35,000$ for sock monkeys and $\$ 2,000$ for a dry composting toilet. Forbes.

Tukker, A. et al., 2008. Fostering change to sustainable consumption and production: an evidence based view. Journal of Cleaner Production, 16(11), pp.1218-1225.

Unruh, G.C., 2000. Understanding carbon lock-in. Energy Policy, 28(12), pp.817-830. Available at: http://www.sciencedirect.com/science/article/pii/S0301421500000707.

Vasileiadou, E., Huijben, J.C.C.M. \& Raven, R.P.J.M., 2016. Three is a crowd? Exploring the potential of crowdfunding for renewable energy in the Netherlands. Journal of Cleaner Production, 128, pp.142-155. Available at: http://www.sciencedirect.com/science/article/pii/S0959652615007489.

Vismara, S., 2018. Sustainability in Equity Crowdfunding. Technological Forecasting and Social Change.

Wainstein, M.E. \& Bumpus, A.G., 2016. Business models as drivers of the low carbon power system transition: a multi-level perspective. Journal of Cleaner Production, 126, pp.572585.

Available

at: http://www.sciencedirect.com/science/article/pii/S0959652616002845.

Wehnert, P., Baccarella, C. V \& Beckmann, M., 2018. In crowdfunding we trust? Investigating 
crowdfunding success as a signal for enhancing trust in sustainable product features. Technological Forecasting and Social Change. Available at: http://www.sciencedirect.com/science/article/pii/S0040162517308831.

World Bank, 2013. Crowdfunding's Potential for the Developing World, Finance and Private Sector Development Department. Washington, DC. 